\title{
Catfish Oil (Pangasius hypophthalmus) effect to ferritin and sTfR in iron deficiency anemia
}

\author{
Hersanti Sulistyaningrum ${ }^{1 *}$, Fronthea Swastawati ${ }^{2}$, Maria Mexitalia ${ }^{3}$, Etika Ratna Noer $^{1}$
}

\begin{abstract}
Background: Iron deficiency anemia is a micronutrient problem and the prevalence is still high. Catfish oil (Pangasius hypophthalmus) is a natural source of heme iron which can improve body iron levels.

Objectives: This study was aimed to examine and analyze the effect of catfish oil on ferritin and sTfR levels in male wistar rats with iron deficiency anemia models.

Materials and Methods: This study was conducted on male wistar rats which were divided into groups C-(standard feed), C+ (standard feed but had the iron removed), XI (standard feed without iron but was supplemented with catfish oil), X2 (standard feed without iron but was supplemented with ferrous sulfate) for 14 days. Ferritin and sTfR levels were measured before and after intervention using ELISA.

Results: The study showed an increase ferritin levels in X1 (21.87 ng/ml \pm 0.76$), X 2(24.47 \mathrm{ng} / \mathrm{ml} \pm 0.54)$ and there was no significant difference between the two ( $p=0.069$; $p>0.05)$; a decrease in $C-(0.25 \mathrm{ng} / \mathrm{ml} \pm 0.43), C+(0.32$ $n g / m l \pm 0.059)(p=0.00 ; p<0.05)$. The sTfR levels decreased before and after intervention $(p=0.00 ; p<0.05)$ in $C+$ $(0.24 \mu / m L \pm 0.99), X 1(60.66 \mu / m L \pm 0.29), X 2(62.10 \mu / m L \pm 0.90)$ and increased in $C$ - $(0.40 \mu / m L \pm 0.97)$.

Conclusions: The study indicates ferritin levels increased in the rats receiving catfish oil is not different from the rats that received ferrous sulfate and sTfR levels decreased significantly in wistar rats with iron deficiency anemia receiving catfish oil although the results were not as good as ferrous sulfate supplementation.
\end{abstract}

Keywords: Catfish oil (Pangasius hypophthalmus); Ferritin; Iron Deficiency Anemia; sTfR

\section{BACKGROUND}

Iron is key to the body's metabolism, namely tissue oxygenation through red blood cells. The absorption of iron in the body is regulated in the small intestine, stored in cells in the form of ferritin, and transported by transferrin. Transferrin that binds to iron will be captured by soluble transferrin serum receptors (sTfR) on the surface of cells. ${ }^{1,2}$ Therefore, measuring the serum ferritin level is a sensitive and specific test to diagnose iron deficiency anemia. However, serum ferritin levels require additional examination in the form of checking sTfR levels, especially in iron deficiency anemia sufferers who experience chronic infection or inflammation. This is because sTfR is not affected by infectious conditions. ${ }^{3}$ Iron deficiency anemia can result in, among others, low birth weight (LBW) in infants, decreased iron reserves in infants, anemia in newborn, the impairment of brain growth and development, and inhibition in the production and breakdown of transmitter compounds needed to deliver stimulated messages from one neuron cell to another affecting the work of the brain. ${ }^{3}$

The data of Riskesdas (Basic Health Research) for Indonesia in 2013 about anemia in children 12-59 months show that $28.1 \%$ and $70 \%$ of anemia in children in Central Java is microcytic hypochromic anemia caused by iron deficiency. ${ }^{4}$ Iron deficiency anemia can be prevented by consuming foods rich in iron and iron supplements. The daily iron requirement for children aged two years is $7 \mathrm{mg}$ per day. ${ }^{6}$ Several studies have seen that the use of iron

\footnotetext{
${ }^{1}$ Department of Nutrition Science, Faculty of Medicine, Diponegoro University,Jalan Prof. Sudarto SH, Tembalang, Semarang, Jawa Tengah 50275, Indonesia

${ }^{2}$ Department of Fisheries, Faculty of Fisheries and Marine Sciences, Diponegoro University, Jalan Prof. Sudarto

SH, Tembalang, Semarang, Jawa Tengah 50275, Indonesia

${ }^{3}$ Division Nutrition and Metabolic Disease, Department of Pediatrics, Faculty of Medicine, Diponegoro University

/Dr Kariadi Hospital, Jalan Dr. Sutomo No. 16, Randusari, Semarang, Jawa Tengah 50244, Indonesia

*Correspondence: E-mail: santi.totw@gmail.com

Copyright (C) 2021; Jurnal Gizi Indonesia (The Indonesian Journal of Nutrition), Volume 10 (1), 2021

e-ISSN : 2338-3119, p-ISSN: 1858-4942
} 
supplementation syrups is effective in reducing anemia but has disadvantages such as causing digestive problems and overdose. ${ }^{5-8}$ Athe et al declare that potential extraction of natural iron sources from foods high in iron, such as fish, is still being carried out. ${ }^{6}$ Patin fish (Pangasius hypophthalmus) contains various nutrients and is affordable, making it widely cultivated. Patin fish has higher iron content than other freshwater fish. ${ }^{10}$ One of the processed patin fish (Pangasius hypophthalmus) that contains many nutrients is catfish oil. This oil is obtained from the extraction of patin fish meat. Current researches related to fish mostly determines the potential content of macronutrients such as protein, fat and rarely looks at the micronutrients on fish in dealing with nutritional problems. ${ }^{11}$ Previous studies indicate that catfish oil contains essential compounds for tissue synthesis, such as albumin, zinc ( $\mathrm{Zn}$ ), copper $(\mathrm{Cu})$, and iron $(\mathrm{Fe}){ }^{12}$ The aim of this study to determine the effect of catfish oil (Pangasius hypophthalmus) on ferritin and soluble transferrin serum receptor (sTfR) levels in male wistar rats with iron deficiency anemia models.

\section{MATERIALS AND METHODS}

The research was carried out in February-March 2020. Initial research was in the form of making catfish oil which was carried out at the Food Technology Laboratory of the Department of Nutrition, Diponegoro University, Semarang, continued with elemental $\mathrm{Fe}$ content analysis at the Integrated Laboratory of Diponegoro University Semarang, analysis of the quality of catfish oil (number peroxide and free fatty acid levels) at LPPT UGM, and intervention research on experimental animals at the PSPG PAU UGM Yogyakarta Animal Laboratory for 21 days, from acclimatization to blood collection for the post test. Research on experimental animals has been approved by the Health Research Ethics Committee of the Faculty of Medicine, Undip with the ethical clearance number 161/EC/H/KEPK/FKUNDIP/XII/2019

\section{Catfish Oil Extraction}

The catfish oil (Pangasius hypophthalmus) processed using the wet rendering method. ${ }^{13}$ The meat of patin fish (Pangasius hypophthalmus) was taken and steamed for 30 minutes at a temperature of $95^{\circ} \mathrm{C} .{ }^{14}$ The fish must be fresh and processed immediately because spoiled fish has a cathepsin enzyme that can accelerate spoilage so that the quality of fish oil will be affected. ${ }^{15}$ It was then pressed using a hydraulic press IWT (International Wrench \& Tools) EC-HP-20T at $1378 \mathrm{~Pa}$.

\section{Catfish Oil Purification}

The water and oil of the patin fish were separated using a separatory funnel Schoot Duran $250 \mathrm{ml}$. The catfish oil (Pangasius hypophthalmus) was purified using the Suseno's modification method by adding $3 \%$ of adsorbent in the form of bentonite from the amount of oil at a temperature of $29^{\circ} \mathrm{C} .{ }^{16}$ The oil was then centrifuged with Eba200 Hettich Centrifuge at $6,500 \mathrm{rpm} 10^{\circ} \mathrm{C}$ for 10 minutes to obtain refined catfish oil. Refined catfish oil was stored in dark glass bottles Taiso $15 \mathrm{~mL}$, tightly closed, and not exposed to direct sunlight so that it is safe from oxidative changes. Yield in the process of catfish oil from catfish meat was $12 \%$.

\section{Catfish Oil Analysis Procedure}

Refined catfish oil was duplo tested for value of free fatty acid, peroxide value, and elemental Fe. The method for calculating free fatty acid levels was putting $5 \mathrm{~g}$ of refined catfish oil in Erlenmeyer, then $25 \mathrm{~mL}$ of hot neutral alcohol and $1 \mathrm{~mL}$ of PP indicator were added. It was stirred until homogeneous and titrated with $0.05 \mathrm{~N} \mathrm{NaOH}$ solution until it turned pink for 30 seconds. The method of calculating the peroxide value was putting $5 \mathrm{~g}$ of catfish oil in a $100 \mathrm{~mL}$ flat flask. Then added $30 \mathrm{~mL}$ of chloroform (3: 2) acetic acid solution, shake until all dissolved. $0.5 \mathrm{~mL}$ of saturated KI solution added and let stand in 1 minute. $30 \mathrm{~mL}$ of distilled water added then titrated with $\mathrm{Na} 2 \mathrm{~S} 2 \mathrm{O} 3$ until the yellow color disappears. 0.5 $\mathrm{mL}$ of $1 \%$ starch solution added until the blue color was gone. Elemental Fe of catfish oil measured using XRF Spectrophotometry WDXRF Rigaku Supermini 200.

\section{Experimental Animals}

In this experimental study, randomized pre-post-test design with a control group on white wistar rats (Rattus novergicus) was used. The rats used were male rats aged 4 weeks with a body weight of 150200 grams, healthy, and active. Exclusion criteria were rats with infection and bleeding. Mice that bleed and died during the study will be dropped out. However, none of the mice bleeding or died during 
the study. The samples were randomly divided into four groups, namely groups C- (negative control), $\mathrm{C}+$ (positive control), $\mathrm{X} 1$ (treatment 1 ), and $\mathrm{X} 2$ (treatment 2) consisting of 6 rats, respectively. ${ }^{17}$ Implementation of experimental animals begins with 14-day induction in wistar rats from the $\mathrm{C}+$, $\mathrm{X} 1$, and $\mathrm{X} 2$ groups to create iron deficiency anemia rats by giving standard feed without iron, followed by 14 days of intervention. Selection of 14 days according to the metabolism of iron in the body. ${ }^{18}$ Group C- received standard feed (AIN 93M), C+ received standard feed with the iron removed, $\mathrm{X} 1$ received standard feed with the iron removed and supplemented with catfish oil of $0.0039 \mathrm{ml} /$ day, and $\mathrm{X} 2$ received standard feed without iron supplemented with ferrous sulfate of $0.126 \mathrm{mg} /$ day. All rats took ad libitum. ${ }^{19}$ The standard feed used is AIN $93 \mathrm{M}$ composed of (\% body weight) $46.75 \%$ of corn starch, $14 \%$ of casein, $15.5 \%$ of dextrin, $1 \%$ of vitamin mix, $5 \%$ of sugar, $3.5 \%$ of solca floc- $40,1 \%$ of soybean oil, $0.3 \%$ of mineral mix, $0.25 \%$ of LCystine, and $7 \%$ of choline bitartrate.

Dose of iron given per day to the rats was adjusted to the daily requirement of iron for two years old, namely $7 \mathrm{mg}$ per day. Then it converted to the dose in rats, which is multiplied by 0.018 ( $7 \mathrm{mg} \mathrm{x} 0.018$ $=0.126 \mathrm{mg}$ ). The amount of catfish oil needed to meet the iron needs of rats is $3.5575 \mathrm{mg}$ (Fe requirement: percentage of elemental fe in catfish oil $=0.126 \mathrm{mg}: 3.5418 \%=3.5575 \mathrm{mg}$ ). Ari Ridha

Table 1. The results of Fe Elemental Analysis by Suseno modification method and Hastarini modification method

\begin{tabular}{lcc} 
Mineral Name & $\begin{array}{c}\text { Suseno modification method } \\
\text { Content }(\boldsymbol{\%})\end{array}$ & $\begin{array}{c}\text { Hastarini modification method } \\
\text { Content }(\boldsymbol{\%})\end{array}$ \\
\hline Silicone & $2,8 \pm 1,1$ & $2,5 \pm 0,26$ \\
Phosphor & $0,5 \pm 0,1$ & $0,36 \pm 0,02$ \\
Potassium & $3,1 \pm 0,15$ & $2,1 \pm 0,26$ \\
Fe Elemental & $3,54 \pm 0,22$ & $1,4 \pm 0,22$ \\
\hline
\end{tabular}

The difference between Suseno modification and Hastarini modification was the level of bentonite use in purification, namely the Suseno modification method uses $3 \%$ bentonite while Hastarini uses $1 \%$ bentonite. Bentonite is a clay that contains more than $85 \%$ montmorillonite, brownish in color, has 100-180 mesh of particles, in the form of a powder. The absorption property of bentonite is due to the $0.8924 \mathrm{~g} / \mathrm{ml}$ so that $3.5575 \mathrm{mg}$ is equal to $0.0039 \mathrm{ml}$ $(3.5575 \mathrm{mg} \times 0.8924: 1000=0.0039 \mathrm{ml}){ }^{20}$

Research on experimental animals was carried out after obtaining permission from the Health Research Ethics Commission (KEPK) of the Faculty of Medicine at Diponegoro University Semarang. Ferritin and sTfR levels were measured before and after the intervention using the ELISA kit Elx 800 ELISA reader model with a wavelength of $450 \mathrm{~nm}$ and an $\mathrm{mg} / \mathrm{mL}$ unit. ${ }^{21}$ The data were analyzed using the SPSS 22 program with the Shapiro-Wilk test to determine the normality of data distribution and Paired t-test to determine differences in ferritin and sTfR levels before and after the intervention. ANOVA test followed by Post-hoc Bonferroni was performed to analyze the difference in the effect of the four groups.

\section{RESULTS}

\section{Fe Elemental Analysis of Catfish Oil}

There are several methods of refining fish oil. Before determining the method to be used in this study, the fe elemental test of catfish oil with several methods was carried out. The method tested for its elemental content was the Suseno modification method and the Hastarini modification method. Fe elemental analysis aims to determine the iron content in catfish oil.
Amril et al states that the density of catfish oil is

Copyright (C) 2021; Jurnal Gizi Indonesia (The Indonesian Journal of Nutrition), Volume 10 (1), 2021

e-ISSN : 2338-3119, p-ISSN: 1858-4942 
is higher when compared to the Hastarini modification method so that it affects impurities that are bound to bentonite. The amount of lost impurities causes higher iron content in catfish oil purified using the Suseno modification method. ${ }^{22}$

\section{The Quality of Catfish Oil}

The quality of catfish oil was analyzed by looking at the percentage of free fatty acids and the value of peroxides then compared with the standards issued by IFOS (International Fish Oil Standards).

Table 2. Comparison of catfish oil parameters with IFOS standards

\begin{tabular}{lcl}
\hline Parameter & $\begin{array}{c}\text { Value of purified } \\
\text { catfish oil }\end{array}$ & IFOS Standard \\
\hline Free Fatty Acid & $0,29 \pm 0,07$ & $<1,5 \%$ \\
Peroxide Value & $10,59 \pm 0,04$ & $<5 \mathrm{meq} / \mathrm{kg}$ \\
\hline
\end{tabular}

The low level of free fatty acids in catfish oil in this study shows that catfish oil has good quality, but it had higher peroxide value than the International Fish Oil (IFOS) standard, which was $10.59 \mathrm{meq} / \mathrm{kg}$. The addition of bentonite in the purification stage can reduce the free fatty acid levels in catfish oil because it can absorb the non-glyceride components of free fatty acids. It also causes maximum absorption of impurity components, which can allow natural antioxidants to be absorbed so that the oxidation stability of fish oil is affected especially in peroxide number result. ${ }^{16}$

\section{Experimental Animals Results Ferritin Level}

The ferritin levels in rats were measured before and after the intervention. Based on the Shapiro Wilk test with $p>0.05$, the data were normally distributed.

Table 3. Differences in Rat Ferritin Levels before and after Intervention

\begin{tabular}{|l|c|c|c|c|c|}
\hline Marker Group & \multicolumn{1}{|c|}{ C- } & C+ & X1 & X2 & $\mathbf{p}^{\mathbf{1}}$ \\
\hline $\begin{array}{l}\text { Ferritin } \\
\text { (ng/mL) }\end{array}$ & & & & & \\
\hline Pre & & & & & \\
\hline Post & $61.94 \pm 0.86^{\mathrm{b}, \mathrm{c}, \mathrm{d}}$ & $37.34 \pm 1.00^{\mathrm{a}, \mathrm{d}}$ & $36.10 \pm 0.84^{\mathrm{a}}$ & $35.33 \pm 0.48^{\mathrm{a}, \mathrm{b}}$ & 0.001 \\
\hline $\boldsymbol{\Delta}$ & $61.69 \pm 0.72^{\mathrm{b}, \mathrm{c}, \mathrm{d}}$ & $37.02 \pm 0.96^{\mathrm{a}, \mathrm{c}, \mathrm{d}}$ & $57.98 \pm 1.34^{\mathrm{a}, \mathrm{b}}$ & $59.81 \pm 0.45^{\mathrm{a}, \mathrm{b}}$ & 0.001 \\
\hline $\mathbf{p}$ & $-0.25 \pm 0.43^{\mathrm{c}, \mathrm{d}}$ & $-0.32 \pm 0.059^{\mathrm{c}, \mathrm{d}}$ & $21.87 \pm 0.76^{\mathrm{a}, \mathrm{b}, \mathrm{d}}$ & $24.47 \pm 0.54^{\mathrm{a}, \mathrm{b}, \mathrm{c}}$ & 0.001 \\
\hline
\end{tabular}

Four groups of rats ( $\mathrm{n}=6$ each groups) consist C-: control healthy, $\mathrm{C}+$ : control iron deficiency anemia, X1: catfish oil (Pangasius hypophthalmus) of $0.0039 \mathrm{ml} /$ day treatment, X2: ferrous sulfate of $0.126 \mathrm{mg} /$ day treatment; $\mathrm{p}=$ value between pre and post treatment were analysed using Paired $\mathrm{t}-$ test; $\mathrm{p}^{1}=$ value between all groups were analysed using one-way ANOVA test with post hoc Bonferroni ${ }^{\mathrm{a}}=\mathrm{p}<0.05$ compared as $\mathrm{C}-{ }^{\mathrm{b}}=\mathrm{p}<0.05$ compared as $\mathrm{C}+,{ }^{\mathrm{c}}=\mathrm{p}<0.05$ compared as $\mathrm{X} 1,{ }^{\mathrm{d}}=\mathrm{p}<0.05$ compared as $\mathrm{X} 2 . \Delta$ changes between pre and post value. Significant if $\mathrm{p}<0.05$.

The highest mean ferritin level after the treatment in C- of $61.69 \pm 0.72 . \mathrm{X} 1$ and $\mathrm{X} 2$ have increased ferritin levels while the ferritin levels of $\mathrm{C}$ - and $\mathrm{C}+$ decreased. This confirms that standard feed and standard feed with the iron removed cannot increase ferritin levels in rats. X2 that received iron supplements in the form of ferrous sulfate has the most significant increase in ferritin levels before and after the treatment. X1 rats supplemented with catfish oil have increased ferritin levels but still less than X2. The results of the Paired- T-Test on the ferritin levels before and after the treatment for each group show a significant difference with $\mathrm{P}=0.001$ $(\mathrm{P}<0.05)$.
The mean difference in ferritin levels for each group after the treatment shows in table 3. The mean ferritin levels of X2 and C- are significantly different but not too much, namely $1.88 ; \mathrm{p}=0.013$. Likewise, $\mathrm{X} 1$ has a significantly different value from C- with not too far difference, namely $3.7 ; \mathrm{p}=$ 0.00 . The mean ferritin levels of $\mathrm{X} 1$ and $\mathrm{X} 2$ are not significantly different $(p=0.069 ; p>0.05)$, but the mean ferritin level of $\mathrm{X} 1$ is less than $\mathrm{X} 2$. This indicates that the supplementation of catfish oil has a similar effect to ferrous sulfate in increasing ferritin levels. Compared with $\mathrm{C}$-, the order of interventions from the most to the least effective is $\mathrm{X} 2, \mathrm{X} 1$, and $\mathrm{C}+$. 


\section{Soluble Transferrin Serum Receptor (sTfR) Level}

The sTfR levels were analyzed before and after the treatment in all groups. The sTfR level data were tested for normality using Shapiro Wilk, and the results of the distribution of sTfR levels were normal with $\mathrm{p}>0.05$.

The results of Paired T-Test show a significant difference in sTfR levels before and after the treatment with $\mathrm{P}=0.00(\mathrm{P}<0.05)$. Table 5 shows a decrease in sTfR levels of $\mathrm{C}+, \mathrm{X} 1$, and $\mathrm{X} 2$ and an increase in the sTfR level of C-. The most significant decrease in sTfR levels was found in
$\mathrm{X} 2$. The decrease in sTfR levels of X1 is also quite significant but less than that of $\mathrm{X} 2$.

There is a significant difference in the sTfR levels of each group after the treatment with $\mathrm{p}<0.05$. The largest difference is between $\mathrm{C}$ - and $\mathrm{C}+(-$ 63.38) and the smallest between $\mathrm{C}$ - and $\mathrm{X} 2$ (1.83). The difference in sTfR levels between X1 and X2 is not too significant. The order of mean difference of sTfR levels, compared with $\mathrm{C}$-, from the highest to the lowest is $\mathrm{C}+, \mathrm{X} 1$, and $\mathrm{X} 2$; it means that the order of interventions from the most to the least effective in reducing sTfR levels is $\mathrm{X} 2, \mathrm{X} 1$, and $\mathrm{C}+$.

Table 4. Differences in sTfR before and after Intervention

\begin{tabular}{|c|c|c|c|c|c|}
\hline $\begin{array}{ll}\text { Marker } & \text { Group } \\
\end{array}$ & C- & $\mathrm{C}+$ & X1 & $\mathrm{X} 2$ & $\mathbf{p}^{1}$ \\
\hline \multicolumn{6}{|l|}{ sTfR Level $(\mu / \mathrm{mL})$} \\
\hline Pre & $6.87 \pm 0.25^{b, c, d}$ & $70.89 \pm 0.49^{a}$ & $71.30 \pm 0.43^{\mathrm{a}}$ & $71.20 \pm 0.48^{\mathrm{a}}$ & 0.001 \\
\hline Post & $7.27 \pm 0.29^{\mathrm{b}, \mathrm{c}, \mathrm{d}}$ & $70.65 \pm 0.52^{\mathrm{a}, \mathrm{c}, \mathrm{d}}$ & $10.37 \pm 0.45^{\mathrm{a}, \mathrm{b}, \mathrm{d}}$ & $9.10 \pm 0.50^{\mathrm{a}, \mathrm{b}, \mathrm{c}}$ & 0.001 \\
\hline$\Delta$ & $0.40 \pm 0.97^{\mathrm{c}, \mathrm{d}}$ & $-0.24 \pm 0.99^{\mathrm{c}, \mathrm{d}}$ & $-60.66 \pm 0.29^{\mathrm{a}, \mathrm{b}, \mathrm{d}}$ & $-62.10 \pm 0.90^{\mathrm{a}, \mathrm{b}, \mathrm{c}}$ & 0.001 \\
\hline $\mathbf{p}$ & 0.001 & 0.001 & 0.001 & 0.001 & \\
\hline
\end{tabular}

Four groups of rats ( $\mathrm{n}=6$ each groups) consist C-: control healthy, $\mathrm{C}+$ : control iron deficiency anemia, X1: catfish oil (Pangasius hypophthalmus) of $0.0039 \mathrm{ml} /$ day treatment, $\mathrm{X} 2$ : ferrous sulfate of $0.126 \mathrm{mg} /$ day treatment; $\mathrm{p}=\mathrm{value}$ between pre and post treatment were analysed using Paired $t$-test; $\mathrm{p}^{1}=$ value between all groups were analysed using one-way ANOVA test with post hoc Bonferroni ${ }^{a}=\mathrm{p}<0.05$ compared as $\mathrm{C}-{ }^{\mathrm{b}}=\mathrm{p}<0.05$ compared as $\mathrm{C}+,{ }^{\mathrm{c}}=\mathrm{p}<0.05$ compared as $\mathrm{X} 1,{ }^{\mathrm{d}}=\mathrm{p}<0.05$ compared as $\mathrm{X} 2 . \Delta$ changes between pre and post value. Significant if $\mathrm{p}<0.05$.

\section{DISCUSSION}

Fish is a source of heme that has economic value so that it can be an alternative in fulfilling iron needs. 100 grams of catfish contains $1.6 \mathrm{mg}$ of iron. Meanwhile, humans, especially children, need $7 \mathrm{mg}$ of iron per day. ${ }^{1,10}$ Therefore, to meet these needs, children should consume a very large amount of fish. Matthew S Wheal et al. in their study show that the iron in fish is mostly heme of around $20 \%$ to $90 \%$ and bioavailability of $23 \%$, meaning that humans can absorb iron in the form of heme from fish by $4.6 \%$ to $20.7 \% .^{23}$ The processed fish products in the form of fish oil were used in the study because it has higher iron than fish meat.

The iron content in the catfish oil (Pangasius hypophthalmus) purified by the Suseno's modification was $3.5 \%$. The density of catfish oil based on the study of Ari Ridha Amril et al. analyzing the bio-lubricant synthesis of patin fish waste oil was $0.8924 \mathrm{~g} / \mathrm{ml}$, meaning that $1 \mathrm{ml}$ of catfish oil (Pangasius hypophthalmus) contains
$31.15 \mathrm{mg}$ of iron $(3.5 \%$ x $0.89 \mathrm{~g}: 1000=31.15$ $\mathrm{mg}){ }^{16,22}$

This study demonstrates that giving catfish oil can increase ferritin levels due to its heme content although it is not as significant as iron supplementation in the form of ferrous sulfate. This study shows that giving catfish oil can increase ferritin levels because of its heme content, although its value is not higher than iron supplementation in the form of ferrous sulfate. This is in line with the previous study by Fu-Rong Wang et al. in their study on extracting squid ink melanin-Fe for the treatment of iron deficiency anemia in rats showed that there was an increase in ferritin levels in rats with iron deficiency after supplemented with squid ink melanin-Fe. ${ }^{24}$ The bioavailability of heme iron is higher than non-heme iron, thereby accelerating the increase in ferritin levels as more iron is absorbed. Besides, non-heme iron sources in plantbased foods contain substances that inhibit iron absorption, such as phytic acid, calcium, and 
polyphenols. Iron reserves in people consuming heme are higher than those consuming non-heme iron. ${ }^{25}$ Timmer et al. through their study also stated that there were differences in ferritin levels between people who consume heme iron every day and those who consume non-heme; the more heme is consumed, the higher the ferritin levels will be. ${ }^{26}$ Another study by Isabel Young et al. stated that food intake rich in heme (beef, mutton, poultry, and fish) can maintain ferritin levels. ${ }^{27}$

Deficiency anemia is characterized by a lack of iron in erythropoiesis activity, high levels of serum transferrin receptors, low levels of ferritin, and decreased levels of $\mathrm{Hb}$. This study shows that the serum transferrin receptor levels in iron deficiency anemia are high. The mechanism is in the small intestine where the amount of iron absorbed is adjusted to the body's needs. The body's need for iron is determined by DMT-1 and ferroportin levels found in the villi of the duodenum. Iron deficiency anemia causes an increase in DMT-1 expression resulting in the increased mechanism of transferrin receptor activity. Transferrin receptors are commonly used as a parameter of erythropoiesis activity. ${ }^{21}$

There was a significant decrease in sTfR levels in the group of rats that received iron supplements in the form of ferrous sulfate and catfish oil (Pangasius hypophthalmus) in this study. In the early phase of iron deficiency anemia, iron reserves in the liver, spinal cord, and spleen decreased, but the sTfR levels were still stable. In the second phase, iron levels decrease while sTfR levels increaseConsumption of heme foods can increase ferritin levels and reduce sTfR levels because the need for iron is fulfilled. ${ }^{21,24,29}$ Less food intake containing heme iron, such as red meat, poultry, and fish, high intake of non-heme iron from plants, and the high consumption of foods containing substances inhibiting iron absorption causes iron deficiency anemia. This was put forward by Nils Milman in his study showing that $54 \%$ of the food intake containing heme iron, such as meat and fish, in women of childbearing age in Europe from 1993 to 2015 was still below the daily iron requirement. ${ }^{30}$ Giving catfish oil can be an alternative in reducing STfR levels because a previous study states that consumption of ferrous sulfate can disrupt good bacteria in the large intestine, increase infection and inflammation in the digestive tract, and increase free radicals from unabsorbed ferrous iron sulfate. When iron enters the body, some will be absorbed in the upper gastrointestinal tract and some other will enter the large intestine and react to superoxide and hydrogen peroxide causing free radicals through the Fenton reaction. ${ }^{31}$ A similar study was conducted by $\mathrm{Fu}$ Rong Wang et al. stated that the treatment group that received squid ink melanin-Fe experienced a decrease in sTfR levels and had fewer side effects than the group receiving ferrous sulfate. ${ }^{24}$ This shows that the use of natural Fe sources is safer. ${ }^{31}$ The other study conducted by Al-Alimi et al. stated that the prevalence of iron deficiency anemia among college students in Yemen was $30.4 \%$ due to the lack of iron intakes, such as red meat, fish, or poultry. ${ }^{32}$ Lack of iron-rich intake is often associated with family income, eating habits, and lifestyle. Nanna Roos et al. stated that the habit of consuming fish cooked into soup by poor rural Cambodians around the Mekong river can meet $36 \%$ of the daily needs of iron in women of childbearing age. Fish cooked into soup has an iron bioavailability of $25 \%$. This further confirms a great potential in the development of processed fish products as a source of natural iron. ${ }^{33}$

\section{CONCLUSIONS}

Giving catfish oil (Pangasius hypophthalmus) influences ferritin and soluble transferrin serum receptors (sTfR) levels. Ferritin levels increase while sTfR levels decrease significantly in male wistar rats with iron deficiency anemia given catfish oil although the results are were not higher than iron supplementation in the form of ferrous sulfate. However, the values of the ferritin level increase and sTfR level decrease in the rats receiving catfish oil are not much different from those receiving ferrous sulfate. It is recommended that further research regarding the bioavailability of iron in catfish oil (Pangasius hypophthalmus) and levels of iron in the tissues that store iron be conducted.

\section{ACKNOWLEDGMENT}

The researchers would like to thank the Integrated Laboratory of Diponegoro University, the Food Technology Laboratory of the Nutrition Science Department of Diponegoro University, the Experimental Animal Laboratory of the Food and Nutrition Study Program of Gadjah Mada University, and all related parties for their

Copyright (C) 2021; Jurnal Gizi Indonesia (The Indonesian Journal of Nutrition), Volume 10 (1), 2021 e-ISSN : 2338-3119, p-ISSN: 1858-4942 
cooperation and assistance in completing this research. The authors received no financial support for this research, authorship, and publication of this article.

\section{REFERENCES}

1. Burke RM, Leon JS, Suchdev PS. Identification, prevention and treatment of iron deficiency during the first 1000 days. Nutrients. 2014;6(10):4093-114.

2. World Health Organization. Serum transferrin receptor levels for the assessment of iron status and iron deficiency in populations. WHO Vitam Miner Nutr Inf Syst [Internet]. 2014;4-7. Available from: http://apps.who.int/iris/bitstream/10665/133707/ 1/WHO_NMH_NHD_EPG_14.6_eng.pdf?ua=1

3. Goddard AF, James MW, McIntyre AS, Scott BB. Guidelines for the management of iron deficiency anaemia. Gut. 2011;60(10):1309-16.

4. Falkingham M, Abdelhamid A, Curtis P, Fairweather-Tait S, Dye L, Hooper L. The effects of oral iron supplementation on cognition in older children and adults: A systematic review and meta-analysis. Nutr J. 2010;9(1):1-16.

5. Badan Penelitian dan Pengembangan Kesehatan. Riset Kesehatan Dasar (RISKESDAS 2013). Jakarta: Kementerian Kesehatan RI; 2013.

6. Janus J, Moerschel SK. Evaluation of anemia in children. Am Fam Physician. 2010;81(12):146371.

7. Athe R, Rao MVV, Nair KM. Impact of ironfortified foods on $\mathrm{Hb}$ concentration in children ( $<10$ years): A systematic review and metaanalysis of randomized controlled trials. Public Health Nutr. 2014;17(3):579-86.

8. Short MW, Domagalski JE. Iron deficiency anemia: Evaluation and management. Am Fam Physician. 2013;87(2):98-104.

9. Marks PW. Evaluation of anemia in children and adults. Nonmalignant Hematol Expert Clin Rev Quest Answers. 2016;3-12.

10. Kementerian RI. Tabel Komposisi Pangan Indonesia. Jakarta: Kementerian Kesehatan RI; 2018. 1-135 p.

11. Jairoun AA, Shahwan M, Zyoud S. Fish oil supplements, oxidatives status, and compliance behaviour: Regulatory challenges and opportunities. PLoS One. 2020;15(12):1-12.

12. Dewi IS, Hastuti US, Lestari U, Suwono H. The effects of kinds of lumus and the storage period on the quality of patin Wadi based on the results of nutrient tests. AIP Conf Proc [Internet]. 2017;1844(May):1-8. Available from: https://doi.org/10.1063/1.4983430

13. Hastarini E, Fardiaz D. Karakteristik Minyak Ikan Dari Limbah Pengolahan Filet Ikan Patin. Agritech. 2012;32(4):403-10.

14. Estiasih T. Minyak Ikan: Teknologi dan Penerapannya untuk Pangan dan Kesehatan. Jakarta: Graha Ilmu; 2009.

15. Swastawati F, Al-Baarri AN, Agustini TW, Dewi EN, Wijayanti I, Prasetyo DYB, et al. Crude Cathepsin Activity and Quality Characteristic of Smoked Catfish (Pangasius pangasius) Processed by Different Smoking. J Teknol dan Ind Pangan. 2016;

16. Suseno SH, Nurjanah, Jacoeb AM, Saraswati. Purification of Sardinella sp., oil: Centrifugation and bentonite adsorbent. Adv J Food Sci Technol. 2014;6(1):60-7.

17. World Health Organization. General Guidelines for Methodologies on Research and Evaluation of Traditional Medicine. Geneva World Heal Ornganization. 2000;

18. Saito H. Metabolism of Iron Stores. Nagoya J Med. 2014;76:235-54.

19. Lyden F. Handling Methods of Laboratory Mice and Rats. Vol. 657, Saint Louis University Biology Department. Swedish; 2016.

20. Amril AR, Irdoni, Nirwana. Sintesis BioPelumas dari Minyak Limbah Ikan Patin dengan Pengaruh Kecepatan Pengadukan dan Suhu Reaksi. Jom F Tek. 2016;3(1):1-6.

21. Astuti R, Subagyo HW, Muis SF. Serum Transferrin Receptors of Iron Deficiency Anemic Rats That Feeding Tempe Fortification Combination Iron and Vitamin A. Proceeding International Seminar Education Technology. 2016;293-9.

22. Sari, R.N., Utomo, B.S.B, Basmal, J., \& Hastarini E. Refining of Pangasius Oil from Fish Smoking By-products. JPB Kelaut dan Perikan. 2016;11(2):171-82.

23. Wheal MS, Decourcy-Ireland E, Bogard JR, Thilsted SH, Stangoulis JCR. Measurement of haem and total iron in fish, shrimp and prawn using ICP-MS: Implications for dietary iron intake calculations. Food Chem. 2016;201:2229.

24. Wang FR, Xie Z-G, Ye X-Q, Deng S-G, Hu YQ, Xin G, et al. Effectiveness of Treatment of Iron Deficiency Anemia in Rats with Squid Ink Melanin-Fe. R Soc Chem. 2014;5:123-8.

25. Skolmowska D, Głąbska D. Analysis of heme and non-heme iron intake and iron dietary sources in adolescent menstruating females in a national Polish sample. Nutrients. 2019;11(5):121.

Copyright (0) 2021; Jurnal Gizi Indonesia (The Indonesian Journal of Nutrition), Volume 10 (1), 2021

e-ISSN : 2338-3119, p-ISSN: 1858-4942 
26. Timmer TC, de Groot R, Rijnhart JJM, Lakerveld J, Brug J, Perenboom CWM, et al. Dietary intake of heme iron is associated with ferritin and hemoglobin levels in Dutch blood donors: Results from Donor InSight. Haematologica. 2020;105(10):2400-6.

27. Young I, Parker HM, Rangan A, Prvan T, Cook RL, Donges CE, et al. Association between haem and non-haem iron intake and serum Ferritin in healthy young women. Nutrients. 2018;10(1):113.

28. Gropper S., Smith JL, Groff JL. Advanced Nutrition and Human Metabolisme. 5th ed. Wadsworth Cengange Learning; 2009.

29. Milman NT. Dietary iron intake in women of reproductive age in Europe: A review of 49 studies from 29 countries in the period 19932015. J Nutr Metab. 2019;2019:1-14.

30. Carrier J, Aghdassi E, Cullen J, Allard JP. Iron supplementation increases disease activity and vitamin $\mathrm{E}$ ameliorates the effect in rats with dextran sulfate sodium-induced colitis. J Nutr. 2002;132(10):3146-50.

31. Werner T, Wagner SJ, Martínez I, Walter J, Chang JS, Clavel T, et al. Depletion of luminal iron alters the gut microbiota and prevents Crohn's disease-like ileitis. Gut. 2011;60(3):325-33.

32. Al-Alimi AA, Bashanfer S, Morish MA. Prevalence of Iron Deficiency Anemia among University Students in Hodeida Province, Yemen. Anemia. 2018;2018.

33. Roos N, Thorseng H, Chamnan C, Larsen T, Gondolf UH, Bukhave K, et al. Iron content in common Cambodian fish species: Perspectives for dietary iron intake in poor, rural households. Food Chem. 2007;104(3):1226-35. 